\title{
Krasnoyarsk Agglomeration: Idea and Prospects of Development
}

\author{
Vaycheslav I. Polishchuk* \\ Corporation "Krasnoyarsk-2020" JSC \\ 51 Respublike Str., Krasnoyarsk, 660075, Russia
}

Received 03.06.2016, received in revised form 21.08.2016, accepted 15.10.2016

This article was prepared basing on the materials of the "Strategy of socio-economic development of the Krasnoyarsk agglomeration until 2020" developed in 2008-2009 by the Corporation "Krasnoyarsk2020 " JSC, in accordance with the state contract No. 6/2008 GK dated July 28th, 2008. In the course of the socio-economic analysis and planning of processes of accelerated innovation complex development of the seven municipalities - Krasnoyarsk agglomeration - with the heart of the agglomeration - the city of Krasnoyarsk, a multivariate analysis of the current status and future directions of socioeconomic development of "agglomerated" territories was performed. Such factors as domestic and international economic and political competition areas, as well as historical geoeconomic location of the Krasnoyarsk agglomeration achieved by 2008, the industrial, economic, cultural, educational and social levels of development and the potential for further growth were taken into account. The article considers the planning time-frame until 2020.

Keywords: regional development, Krasnoyarsk agglomeration, strategy of socio-economic development, innovative development of the region, modernization of the Krasnoyarsk Krai economy.

According to the "Strategy of socio-economic development of Krasnoyarsk agglomeration until 2020" developed in accordance with the state contract No. 6/2008 GK dated July 28th, 2008.

DOI: 10.17516/1997-1370-2016-9-11-2803-2829.

Research area: economics.

\section{Introduction}

The priority investment project "Integrated socio-economic development of the Krasnoyarsk agglomeration" consisting of 7 municipalities: the city of Krasnoyarsk, the city of Divnogorsk, the city of Sosnovoborsk, Berezovsky District, Emelyanovsky District, Mansky District and Sukhobuzimsky District, was set up in 2008 after the chiefs of 7 municipalities had signed the inter-municipal agreement under the auspices of the governor of the Krasnoyarsk Krai.

Within the framework of the project implementation in 2008-2011 the following strategic documents had been developed:

- The strategy of the socio-economic development of the Krasnoyarsk agglomeration up to 2020

- The layout of territorial planning of the Krasnoyarsk agglomeration

(C) Siberian Federal University. All rights reserved

* Corresponding author E-mail address: v.polishchuk.krsk@gmail.com 
- The investment passport of the Krasnoyarsk agglomeration.

A number of relevant works was prepared, including works on the cultural heritage of the city of Krasnoyarsk, preparation of investment application for the establishment of the Nanotechnology Centre in Krasnoyarsk, development of the scheme of waste treatment in the Krasnoyarsk Krai and a number of other works.

In 2011-2012, in connection with the change of the regional development priorities, the priority investment project "Integrated socioeconomic development of the Krasnoyarsk agglomeration" was placed in the management of the Interdepartmental Commission of the Government of the Krasnoyarsk Krai, and specially designed for its implementation "Corporation "Krasnoyarsk-2020" JSC was disbanded.

\section{Prerequisites for the development and implementation of the project}

The economic, industrial, innovation, transport and logistics, educational and cultural heart of the Krasnoyarsk Krai is its administrative centre, the city of Krasnoyarsk. Krasnoyarsk is also one of the largest centres of Central and Eastern Siberia. Around the city of Krasnoyarsk the Central macro-region of the Krasnoyarsk Krai is formed with the historically most integrated socio-economic space - "Krasnoyarsk agglomeration", geographically defined by a dense transport infrastructure, sustainable socioeconomic ties, "connected" and highly integrated markets: finance, labour, goods and services, including commuting of the population.

Taking into account the well-established in the world practice "technical" definition of any agglomerated socio-economic area, namely transport accessibility for the population of about 1.5 hours by public transport, the historical
Krasnoyarsk agglomeration has included 3 cities Krasnoyarsk, Divnogorsk and Sosnovoborsk and 4 municipal districts: Berezovsky, Emelyanovsky, Mansky and Sukhobuzimsky. (Note: the closed city of Zheleznogorsk, formally has not become the part of the Krasnoyarsk agglomeration because of its special status, but the socio-economic performance of Zheleznogorsk was taken into account in the development of the Krasnoyarsk agglomeration strategic documents).

Due to the fact that the Krasnoyarsk agglomeration like all agglomerated spaces had been developing historically and, accordingly, in quite a "messy" way without any balance, during its development essential long-term risks to the possibilities of its further advance development have formed, including:

- Significant environmental degradation, which negatively effects the level and quality of life of the population

- Increasing of commuting of the working population while the transport infrastructure is not ready for it

- Insignificant development of the transport infrastructure and its inability to meet current and long-term demands of the socioeconomic space of the agglomeration

- Absence of constantly working mechanisms of approval of economic interests of the municipalities included into the Krasnoyarsk agglomeration in order to develop unified socioeconomic policy territorial planning, urban development, solving the issues of the transport infrastructure development and many other interrelated issues that are critical for the balanced and gradual development of highly integrated territories of the agglomeration.

Due to the special importance of the Krasnoyarsk agglomeration socio-economic space for the sustainable development of the Krasnoyarsk Krai and the whole Central and Eastern Siberia, in 2008 - 2009 years the 
"Strategy of the Krasnoyarsk agglomeration development until 2020" was developed on behalf of the government of the Krasnoyarsk Krai (hereinafter referred to as the 'Strategy'). The working group on the development of the strategy included representatives of the Krasnoyarsk Krai Government, administrations of Krasnoyarsk, Divnogorsk and Sosnovoborsk, Sukhobuzimsky, Mansky, Emelyanovsky and Berezovsky municipal districts, representatives of the scientific community and the business community of the Krasnoyarsk Krai, federal and regional industry experts, Russian and international consultants.

In the course of the strategic analysis the following information sources were used:

interviews with industry experts;

documents of administrations and governments of the municipalities included into the Krasnoyarsk agglomeration;

results of sociological research;

reports of international organizations;

documents of the Russian Federation

Government, governments of foreign countries and regions;

analytical reports of investment banks and corporations;
Russian and international industry analytics;

state statistics;

information bases.

During the development of the strategy, the main goal was determined as the growth of the population's well-being. In order to reach this goal the Krasnoyarsk agglomeration should become the best place for life, work, business and creative activities.

In the process of work, both external trends and existing potential and limit of the territory were taken into consideration (Fig. 1).

It is noteworthy that the strategy of the Krasnoyarsk agglomeration socio-economic development was elaborated during the period of the rise of the global financial crisis, which to a large extent had adjusted forecasts and plans for its implementation. At the same time, the financial crisis is a major challenge for the agglomeration and one of the unique opportunities for the development of new projects to enhance the attractiveness of the agglomeration territory. Moreover, the "break" in the development of the economy caused by the crisis provides an opportunity to spend more time on planning, design, calculations and, ultimately, the choice of strategic priorities, taking into account the changing external conditions. During

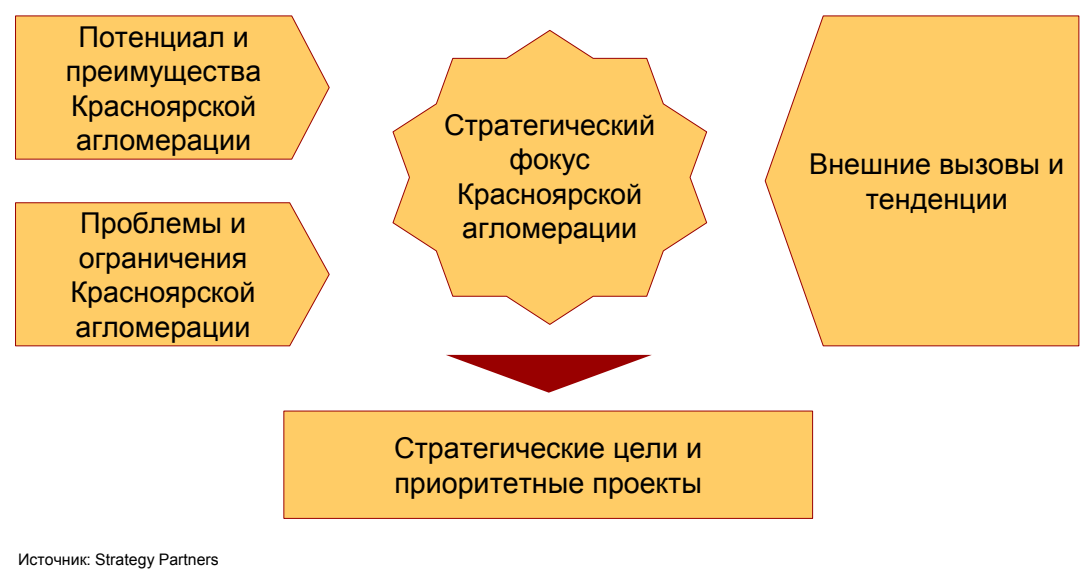

Fig. 1. Interrelation of the factors in determining the strategic focus of the Krasnoyarsk agglomeration 
this period it is most clearly seen that there is a necessity to come back to the fundamental values: the development of the real diversified economy as opposed to the growth due to only financial assets and operations.

In the course of the study, the analysis and proposed recommendations were aimed at searching for the answers to the key questions regarding the development of the Krasnoyarsk agglomeration.

What are the main advantages and limitations of the Krasnoyarsk agglomeration?

Which economic specialization will better suit to meet the external challenges and consider the advantages of the agglomeration?

How would the Krasnoyarsk agglomeration differ from other Siberian and Russian cities and agglomerations?

Which industries have the most potential for growth and correspondingly will become the priority ones for the development and support of the authorities?

What will be the main specialization of each municipality included into the Krasnoyarsk agglomeration?

What are the new requirements to the urban development decisions?

What are the requirements to the supporting sectors of the social sphere, such as healthcare, culture, sports and security?

Implementation of which key projects will allow to reach the strategic goals of the agglomeration development?

The important section of the work have become the calculations of the necessary investments and determination of the financing sources for the proposed projects and initiatives.

\section{Characteristics}

\section{of the Krasnoyarsk agglomeration ${ }^{1}$}

During the development of the strategy, the population of all municipalities whose territories are included into the Krasnoyarsk agglomeration amounted to 1,122 thousand people, accounting for $37 \%$ of the total population of the Krasnoyarsk Krai.

Krasnoyarsk is the capital of the Krasnoyarsk Krai, one of the most economically developed regions of Siberia. It is not only the heart of the emerging agglomeration, but also the economic and business centre of the Siberian region, the preservation and development of which guarantees the access to resources and the preservation of the territorial integrity of the Russian Federation. Krasnoyarsk clearly occupies the central place in the spatial frame of the region, concentrating onethird of the population of the Krasnoyarsk Krai, three quarters of the administrative authority and one-fifth of produced goods.

Krasnoyarsk occupies the second position after Novosibirsk in the Siberian Federal District by the number of infrastructure corridors and population. It is the major link in the SiberianFar Eastern part of Russian space frame and its influence covers large territories of the Ural, Siberian and Far Eastern Federal Districts.

The potential of the Krasnoyarsk agglomeration development is determined by the following factors:

well-developed scientific and educational base;

high level of human resources potential;

possibility to allocate large industrial facilities on the existing industrial sites of the agglomeration;

the possibility of allocating energy-intensive industries while there are relatively cheap sources of electricity;

transportation potential due to the presence of major waterways, federal highways, the Trans-Siberian railway and a major international airport.

Being the heart of the agglomeration, Krasnoyarsk can enhance the development of 
various industries in the field of its influence, but also can limit it, i.e. contribute to the occurence of growth points or depression.

As a part of implementation of transport and transitpotential of the Krasnoyarskagglomeration, the most promising is the development of a diagonal infrastructural corridor to Yakutsk and the continuation of the regional corridor to the south, in Tuva, with its potential conversion into the international infrastructure corridor to Mongolia. Additional opportunities can be obtained through the development of the air corridor from South Asia (India, Pakistan, Nepal, and others) to Canada and the United States.

The assessment of the development potential took into account the growing influence of the Asian market, which each year will consume more and more natural resources. Due to its geographical position, Krasnoyarsk can become a "gateway" for Asian countries to the Siberian region rich in resources and to ensure mutually beneficial economic cooperation.
The efficient development of the Krasnoyarsk agglomeration can be impeded by some problems in the area of economy, natural and climate conditions, ecology and social sphere.

The most acute economic problems are:

1) the predominant role of metallurgy in the processing industry, which increases the dependence of the agglomeration economy on the world market situation and, in particular, metal prices;

2) lowdegreeoftheeconomydiversification, the main share of employment accounts for the sector of public and social services, characterized by the lowest contribution to the GRP of the agglomeration (Fig. 2);

3) low labour productivity compared to developed countries for the whole range of sectors and industries (from 8 to $58 \%$ of the productivity level of industries in the United States).

In addition, it should be noted that the region has low investment attractiveness and the high level of investment risks in comparison with

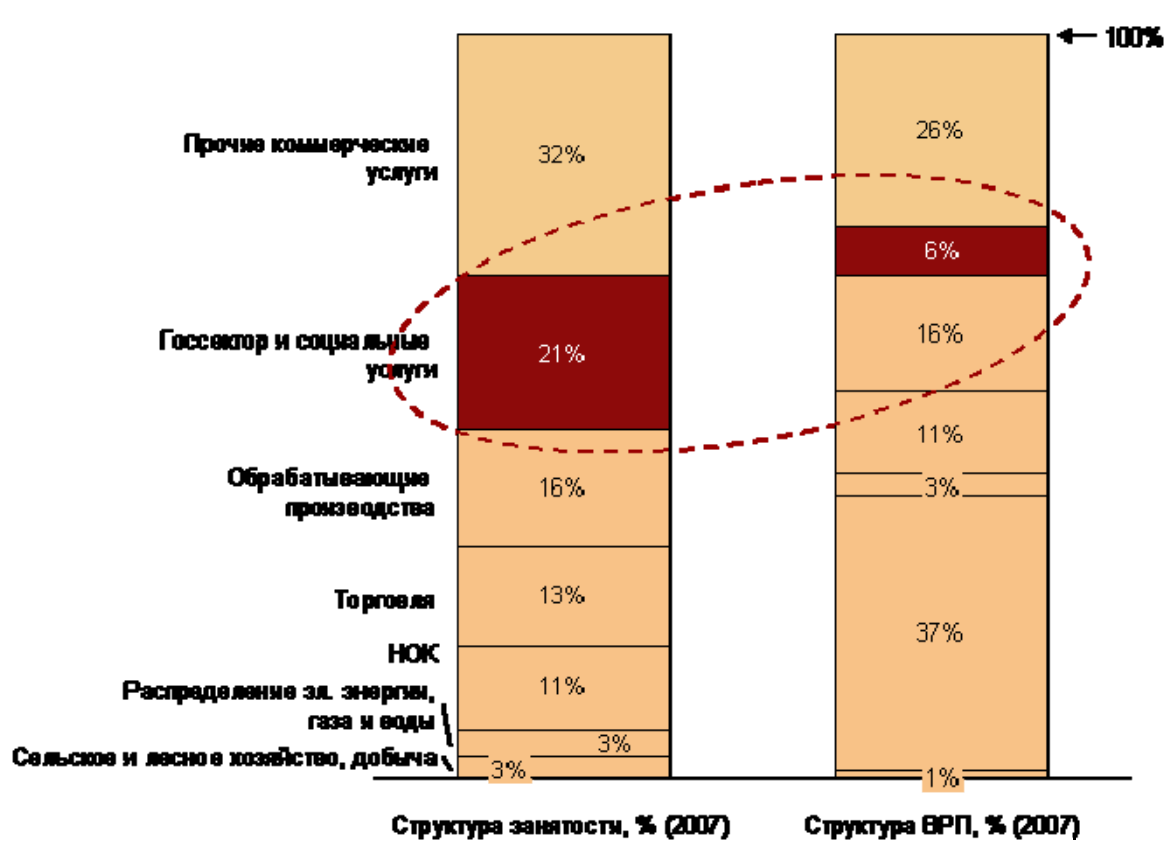

Fig. 2. Correlation of the employment pattern and GRP pattern of the Krasnoyarsk agglomeration (as of the period of the Strategy development) 
neighbouring regions, as well as insufficiently attractive conditions for the development of small business.

An important factor hindering the development of the Krasnoyarsk agglomeration is its territorial remoteness from the major markets and business centres of the Russian Federation. Territorial remoteness along with weak transport infrastructure reduces opportunities for the agglomeration to participate in the delivery to the international market of the products with low added value and a high proportion of transport costs in the cost structure, and leads to higher prices of products imported into the territory of the agglomeration from other regions. This, in general, reduces the mobility of people, goods and business.

Among the climatic factors affecting the development of the agglomeration, the most important is severe climate. It makes the Krasnoyarsk agglomeration unattractive for work and life, as well as limits the list of economic activities that would be effectively developing.

Environmental problems is another important factor limiting the opportunities of the Krasnoyarsk agglomeration development. A high proportion of environmentally harmful and technologically dangerous productions and facilities located in close proximity to residential areas lead to the fact that for many years Krasnoyarsk has been in the list of Russian cities with the most polluted atmosphere. According to the environmental and health services, water in the region's rivers is undrinkable. The Yenisei is contaminated with radioactive wastes of the Krasnoyarsk Mining and Chemical Combine. The situation is worsened even more while some industrial enterprises of Krasnoyarsk do not have sanitary protection zones and do not meet modern requirements for the protection of the environment.

Among the factors that characterize the state of the social sphere in the agglomeration and have an impact on its further development it is necessary to outline the high level of crime, lack of social, educational, sports and cultural infrastructure facilities for the population.

\section{Challenges}

Among the determined external conditions, the most significant ones are the following challenges and tendencies:

- the world financial crisis and economic sanctions;

- growth of economic activity and markets of Asia;

- globalization;

- increasing importance of innovations and human capital;

- increasing competition between the regions of the Russian Federation.

In terms of the developing global financial crisis, the growing importance of the real economic sectors and reduced confidence in the virtual sectors make the economy of the agglomeration with the real sector occupying a significant share in the structure of economy more attractive for potential investors. The safety margin of the agglomeration economy, also due to the high budget security, creates conditions for the acquisition of attractive assets, especially in the field of high technology and innovations. Additional features are potential modernization of the financial system and the prospect of consolidation in some sectors and industries of the agglomeration. An important opportunity that has appeared as a result of the crisis, is a chance to attract to the agglomeration available qualified personnel, including experienced managers from the business centres of the Russian Federation.

Due to the rapid economic and population growth in Asia the region becomes the largest market for consumer goods and services, natural resources and raw materials, production technology, machinery and equipment; as well as 
the major supplier of technology, raw materials, spare parts and human resources. Advantageous geographical location, availability of the Krasnoyarsk Krai's raw materials and resources, as well as knowledge and understanding of the Russian market will enable the Krasnoyarsk agglomeration become an important trading partner for the major Asian countries, as well as act as an intermediary and trade representative between Russian and Asian manufacturers. At the same time, the development of Asian countries as the major manufacturers will result in the need for the agglomeration to adjust to the increasing global competition.

The intensification of globalization accompanied by the active removal of capitalintensive and knowledge-intensive production of western companies into countries of Asian region and Eastern Europe, opens for the Krasnoyarsk agglomeration a wide range of possibilities. In the first place, the agglomeration may place on its territory advanced manufacturing and manufacturing processes, which are relocated by foreign companies. The convenient geographical location - central in relation to Russia and Asia - allows the agglomeration to take the leading role in ensuring the integration of the Russian economy in the world by sourcing and entry to the growing markets in Asia. The growth of global competition at a low (at the moment) competitiveness of the agglomeration economy poses a threat to the possible pushing out of Russian companies not only from international, but also domestic markets.

The increasing role of innovation and human capital opens the possibility for building an innovative economy, but carries the risk of the technological gap growth. A well-developed scientific and educational complex and the presence of high-tech and innovative enterprises, as well as a high proportion of young people will attract talented people to the agglomeration, which is necessary for the creation of the innovative economy with the high added value. The main obstacle for the development of the agglomeration in this way may be the lack of infrastructure for commercialization of research and development, the lack of demand for innovation on the part of business and unfavourable environment for attracting and keeping human resources. Insufficient attention to these problems will increase the risk of technological lagging behind of the agglomeration and the risk of outflow of the best human resources to more attractive regions.

The necessity to attract new residents to the region, funding from the federal centre and private investors determine the fierce competition between Russian regions. As a rule, the regions clearly representing their strategic priorities in the economic and social spheres and implementing long-term development programmes cooperate more efficiently with the above target groups and, as a consequence, develop more rapidly.

Already today it is possible to speak about the manifestations of this competition in different spheres. Thus, the Krasnoyarsk agglomeration is competing with the Novosibirsk agglomeration for leadership in Siberia and with the Irkutsk agglomeration for leadership in Eastern Siberia and the impact on the regions of the Far East. Speaking of certain economic areas and industries, it is worth noting that Krasnoyarsk has to compete with Novosibirsk, Tomsk and Irkutsk in the field of scientific research and education; with Ekaterinburg, Omsk, Irkutsk and Novosibirsk in mechanical engineering; with Altai and Irkutsk regions in terms of significant tourist resources. Moreover, there is the intersection of interests and the competition with Ekaterinburg, Novosibirsk and Irkutsk for key transport corridors; with Irkutsk in terms of effective energy systems; with Kemerovo and Irkutsk regions and the Republic of Sakha-Yakutia for efficient access to natural resources. 
Understanding of its competitive advantages and steady movement in accordance with the chosen economic specialization will allow the agglomeration to become the leader in the competition of large cities and agglomerations of the country.

\section{Strategic choice}

\section{The strategic focus of the agglomeration}

The Krasnoyarsk agglomeration is by far an industrial site mainly focused on products with the low added value. Nevertheless, the problem of territorial remoteness from major markets prevents the agglomeration from successful implementation of this role due to the high cost of transportation. The main external trends, as well as the problems of the agglomeration in economy and quality of life necessitate the displacement of its strategic focus towards the creation of higher added value and a higher level of well-being and quality of life of the population.

Out of all types of possible strategic focus the most attractive in terms of added value is a scientific and educational centre, a centre for entrepreneurship and innovation, service base and an administrative and financial centre (Fig. 3). It should be noted that the Krasnoyarsk agglomeration does not have the potential to become a scientific and educational centre similar to Cambridge or Oxford due to the absence of the key factors of success in this strategic focus: academic schools leading in various fields of scientific activity. The challenge to become an administrative and financial centre is also difficult to implement due to the lack of prerequisites for placing on the territory of the agglomeration headquarters of the largest corporations and financial institutions and the small size of the agglomeration. Development as a service base is a viable option based on the resource potential of the Krasnoyarsk Krai and the active desire of the significant part of the Russian state and business elite for the early development of these resources. The businessas-usual development meaning preservation of the strategic focus of the "industrial site" is also possible. The focus on the development of the Krasnoyarsk agglomeration as a centre for

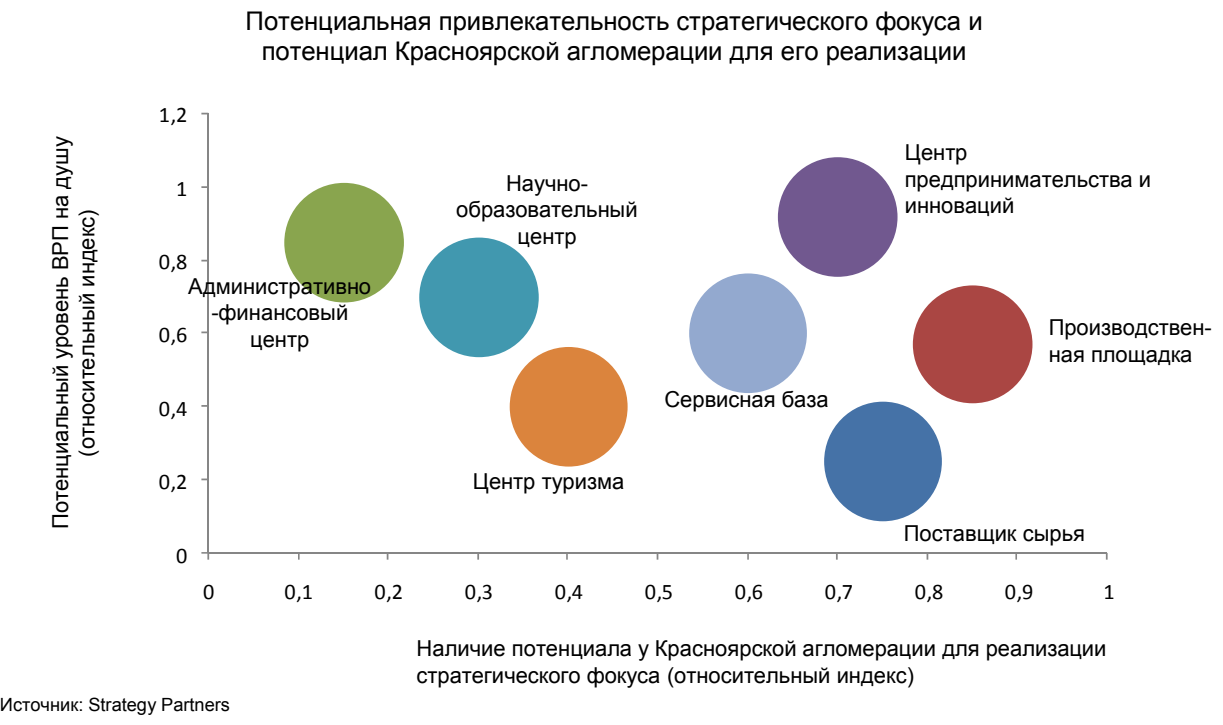

Fig. 3. Comparison of different types of the Krasnoyarsk agglomeration strategic focus in terms of attractiveness and potential for implementation 


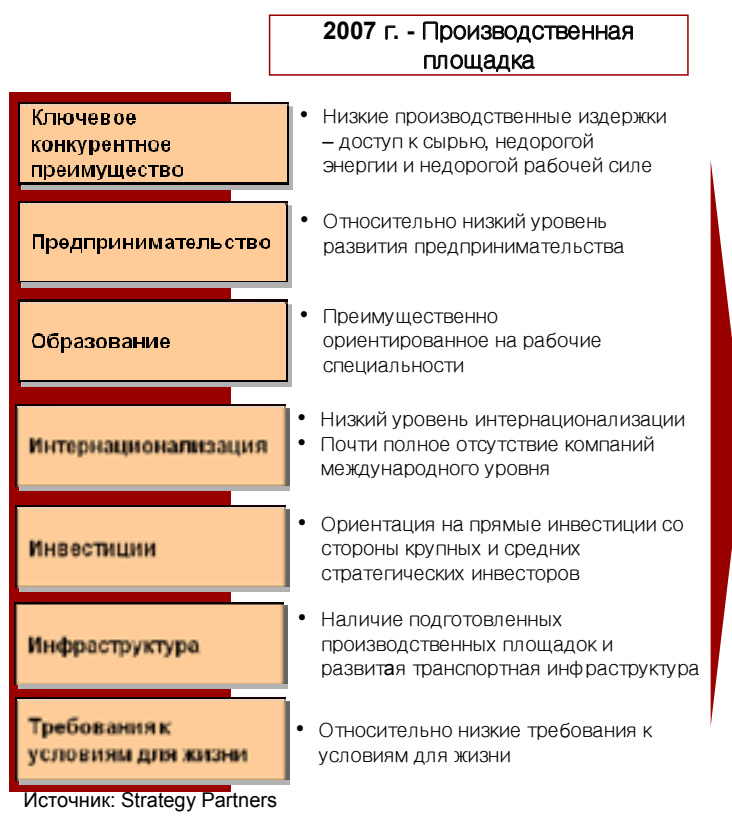

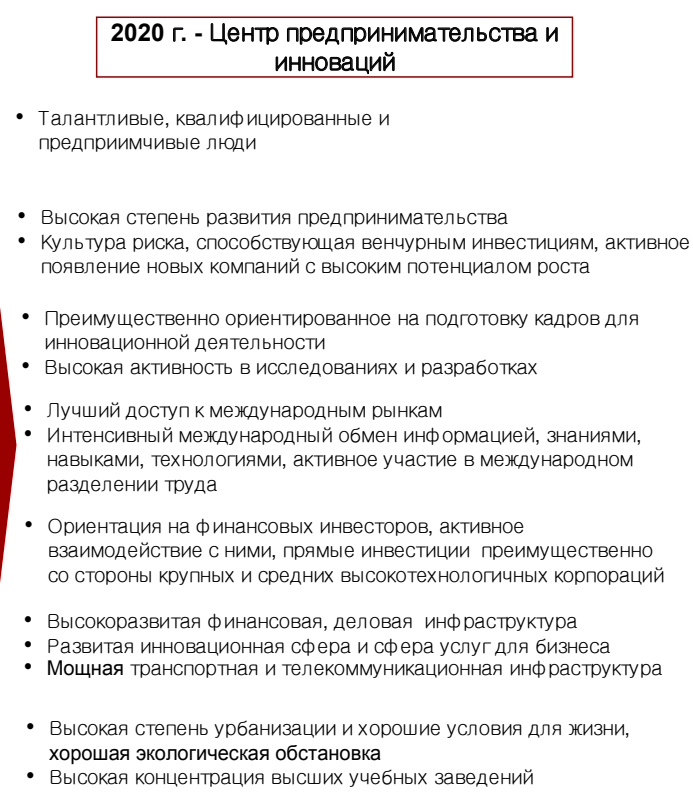

Fig. 4. Change of the strategic focus (specialization) of the Krasnoyarsk agglomeration

entrepreneurship and innovation, even though requires significant effort, has a better chance for success with the existing human resources potential, experience in the field of applied science and a strong industrial base. External trends and challenges also push to the choice of such a strategic focus (Fig. 4).).

Therefore, the most sensible strategic focus of the Krasnoyarsk agglomeration is "The Centre of Entrepreneurship and Innovations".

\section{Positioning}

Geographic proximity to Asia will allow the Krasnoyarsk agglomeration to use the opportunities offered by these growing markets, as well as to mediate between Russia and Asia in the development of trade relations, the exchange of technology, expertise and resources. The high level of development of transport, energy and industrial infrastructure together with the development of business infrastructure will allow the agglomeration to strengthen the already formed impact on the regions of Siberia and the Far East.
In general, the Krasnoyarsk agglomeration potential allows it to position itself as a base for implementation of possibilities of Siberia, the Far East and opportunities for cooperation with the growing Asian countries.

\section{Competitive advantages}

Formation of the Krasnoyarsk agglomeration as a centre for entrepreneurship and innovations will require substantial efforts to change the current position by all the parameters characterizing the designated strategic focus. At the same time, as noted above, the key success factor in this strategic direction will be highquality human capital. Thus, the administration's efforts should be mainly directed at attraction of talented and entrepreneurial people to the agglomeration.

The basis for achieving this goal, in addition to economic benefits, should be comfortable living environment. In the conditions of increasing competition for human capital between the regions, in order to attract the best human resources the Krasnoyarsk agglomeration should 


\section{Центр предпринимательства и инноваций}
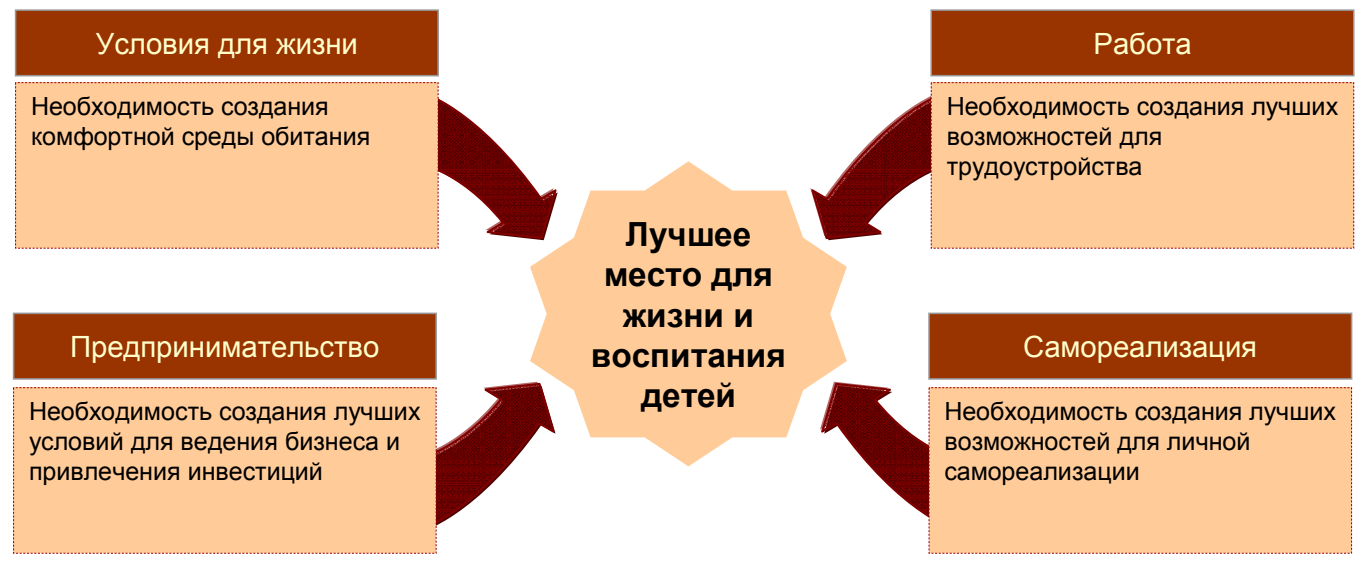

\section{Плацдарм для реализации возможностей Сибири, Дальнего Востока и растущих рынков Азии}

Fig. 5. The strategic focus, positioning and vision of the Krasnoyarsk agglomeration development up to 2020

become a better place for living, working, leisure and personal fulfillment (Fig. 5).

Comfortable living environment means not only high quality living conditions for people, but at the same time productive environment for the emergence and development of new businesses on the territory of the agglomeration, which would require specific efforts of authorities.

The main peculiar feature of the Krasnoyarsk agglomeration and its main competitive advantage should become an established exchange of technologies and competences mainly with Asian countries, and developed innovative and educational infrastructure, modern industrial sites, attractive environment for business development.

In relation to the main competitors (Novosibirsk, Tomsk, Irkutsk) which claim similar strategic orientation and movement towards innovative future, positioning of the Krasnoyarsk agglomeration is clear: industrial, innovative and technological capital of Siberia and the Far East.
Achieving the necessary competitive advantages and development in accordance with the chosen strategic positioning and focus will enable the Krasnoyarsk agglomeration to take the leading position in the Asian part of Russia and become a fast-growing innovation-oriented region, a pole of technological revival of not only Siberia and the Far East, but also the country in general. At the same time the Krasnoyarsk agglomeration can be rightly called the "economic gateway" to Asia, the territory strengthening the real sector of economy as opposed to the western service-oriented regions, as well as become the pole for the growth of Russian competitiveness in innovative production and serve as a mechanism for elimination of inequalities in the social and economic development of the regions of Russia.

\section{Strategic priorities and target performance}

The strategy assumes the achievement of the key goals in the field of economy, quality of life, supporting infrastructure, demography and migration policy by 2020 . 


\section{Economy}

In determining the economic priorities of the Krasnoyarsk agglomeration the following determinants should be taken into account:

Determinants of demand:

1. Objectives of natural resources exploration in the Urals, Siberia and the Far East, developmentoftransportandenergyinfrastructure, as well as modernization of the Russian economy in order to increase its competitiveness, are key determinants of demand for products and professional services for production purposes (machines, technological equipment, instruments, systems and engineering). As a result, Russia along with the CIS countries becomes one of the most attractive markets of industrial goods in the world.

2. Proximity to the new centre of global economic growth - Asian markets - creates the prerequisites for Krasnoyarsk to win the role of the expertise centre on trade with the Asia-Pacific region. This will cause the demand for professional services on the development of business between Russia and Asia. Solving this problem will require the development of a modern business infrastructure, which will be the basis for the functioning on the Krasnoyarsk agglomeration territory of the development institutions and commercial enterprises specializing in Asian markets.

3. With the development of telecommunication infrastructure, there appears a new demand for services provided with the use of remote access, which opens up new opportunities for geographically distant regions. The basis of the demand constitute intellectual professional services characterized by a high level of added value. The main source of demand for outsourcing services in Russian are economically developed regions of the European part of Russia.

4. The development of the agglomeration will require the creation of a modern business, housing, transport and social infrastructure of a new quality, that will stimulate the development of the construction industry, which, in turn, will be a catalyst for the demand for modern construction and finishing materials.

5. Large-scale domestic market (more than $1 \mathrm{mln}$ people) and geographic position providing transport access to the nearby markets (Novosibirsk, Irkutsk and others) allow to create on the territory of the agglomeration a food cluster basing on modern enterprises for the production and distribution of food products and services for the population.

Determinants of quality and the structure of economy:

1. A relatively low current level of labour efficiency and limited access to human resources requires to locate on the territory of the agglomeration only enterprises with the high level of productivity and high added value. For example, engineering, machine engineering, scientific, educational and professional services, as well as enterprises of new economy.

2. The high degree of concentration of the regional economy and the low level of diversification makes its flexibility and ability to stand against crises lower due to the low level of entrepreneurial initiative. It is important to favour the development of medium and small-size businesses (for reference: a medium-size machine engineering company in Germany - $30 \mathrm{mln}$ EURO with 150 employees), which produce final products with high added value and relatively low influence of the scale on the efficiency of operations.

3. High proportion of continuous production also reduces the ability of the economy to adjust to the lower demand in the crisis periods. The increasing share of discrete productions in relation to the continuous ones will increase flexibility and sustainability of the economy.

4. Out-of-date business models, for example: significant degree of vertical integration 
in machine and instrument engineering should be left behind. It is important to stimulate development of modern productions based on business models, which include research and development, assemblage and maintenance, as well as production of unique components and units, when the economy of production does not rely much on the scope of operations.

Peculiar features of the Krasnoyarsk agglomeration:

1. Geographical remoteness does not allow to establish on the territory of the agglomeration enterprises, which produce such goods when the main share of the net cost is transport costs and for which the proximity to the markets is critical. For example, production of mass products, raw materials and semi-finished products with the low level of processing, including production components of the third level.

2. Environmental problems do not allow to locate on the territory of the agglomeration enterprises, which will increase the environmental pollution. Moreover, modernization is required and in the long-term perspective complete removal from the agglomeration territory of existing metallurgical and chemical plants.

3. Severe climate limits the possibilities for the development of some economic sectors, for example agricultural business.

4. Production and technical experience, engineering culture and existing system of human resources training, as well as well-developed energy and transport infrastructure create good prerequisites for the development on the territory of the agglomeration of a modern industrial base, which may include high-tech processing plants.

5. Territorial remoteness from the European part of Russia and the Far East (4 time zones) creates unique opportunity for the establishment on the territory of the agglomeration of the branches of Russian research, project, publishing, engineering, consulting and other organizations.
For these organizations the possibility of increasing the efficient working day for fulfilling tasks and functions (research and development, translations, design, editing of documents, etc.) in the remote territories.

Thus, taking into consideration the potential of the demand, the impact of the transport component in costs, compliance with the experience and traditions of the current economy, compliance with the features of the Krasnoyarsk agglomeration, effect on the improvement of the economic structure and reduction of risks, and compliance with environmental requirements, the most priority sectors and industries can be determined for the Krasnoyarsk agglomeration (Fig. 6).

Let us list the main objectives in the economic field:

1. To ensure the growth of total revenues of enterprises and organizations of the Krasnoyarsk agglomeration up to 2.7 trillion RUB.

2. To increase the gross regional product up to 862 billion RUB per year.

3. To increase average performance by 2.0 times - up to 2,800 thousand RUB per employee per year.

4. To provide existing and newly created knowledge-intensive production with the necessary scientific developments and qualified personnel, and for this purpose to increase the proportion of scientific and educational complex in the structure of the agglomeration economy from 4 to $26 \%$.

5. To increase in the share of mechanical engineering the structure of the manufacturing sector to $35 \%$ by the development of promising areas: forestry, mining, energy, oil and gas engineering.

6. To ensure the development of tourism that could bring the economy up to 19.2 billion RUB of revenues, and for this purpose to contribute to the construction of new hotels and 


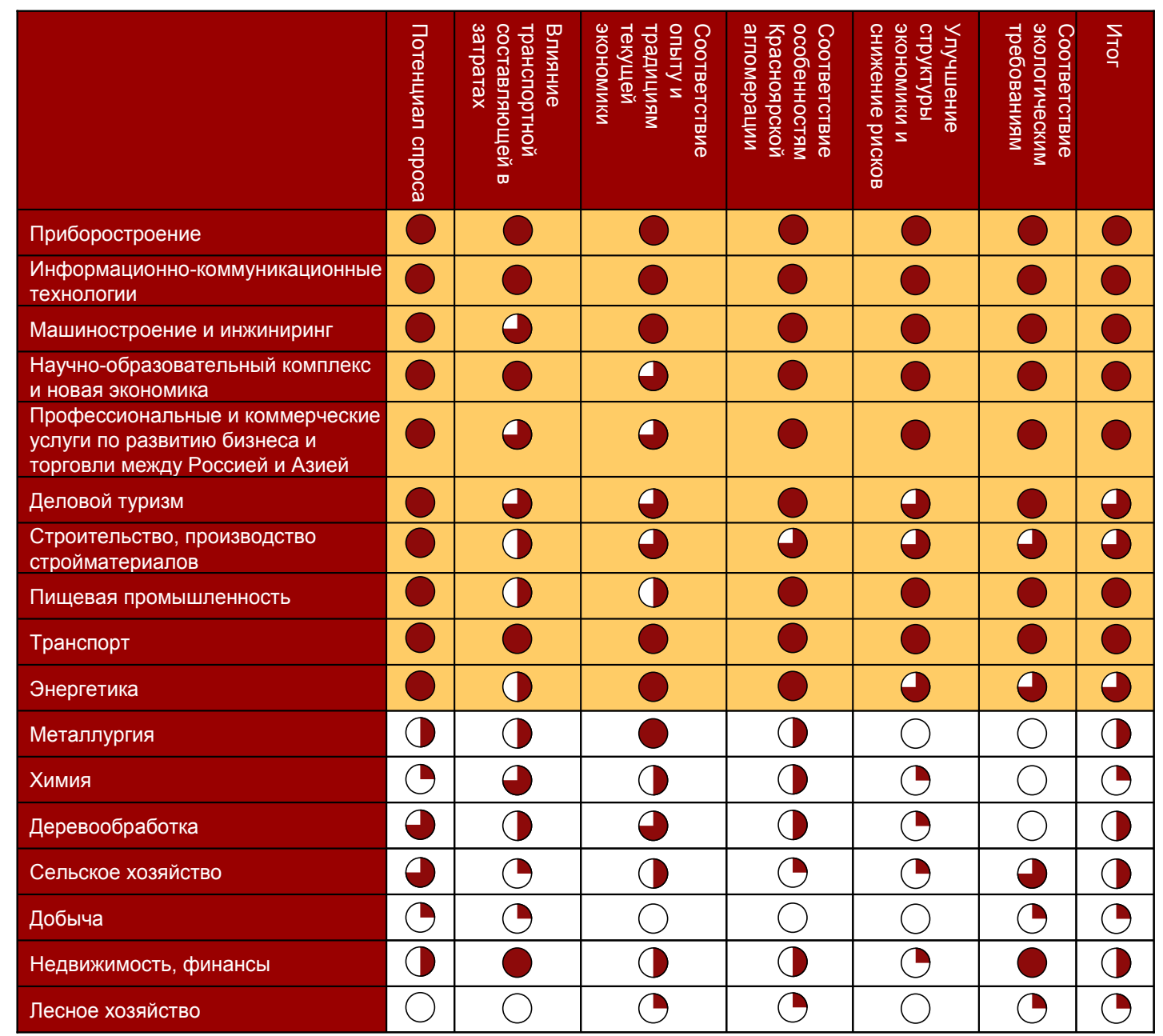

Fig. 6. Determining the priority fields of the Krasnoyarsk agglomeration economy

the development of related industries, such as catering.

7. To provide the growing economy with necessary human resources $(778,000$ employed in the economy).

8. To shift the employment structure in the direction of high-performance industries with high wages.

9. To increase per capita income up to 456 thousand RUB per year.

10. To attract investment in the economy, totaling 1.4 trillion RUB. ${ }^{2}$

Along with the achievement of quantitative indicators of economic development, the essential element of the implementation of the strategy is to create conditions for the development of entrepreneurship and attracting companies to the territory of the Krasnoyarsk agglomeration. In this regard, additional priority and, as a consequence, the focus of the efforts of regional authorities should be the development of factors such as personnel training, the construction of industrial sites with ready transportation and energy infrastructure, focused work with the investors, the formation of a sufficient amount of office space, etc.

\section{Quality of life}

Since all the priority sectors of the economy without any exception present a demand for highly 
qualified managers and specialists, for which the important factors of the territory attractiveness along with well-paid and interesting work are safety, environmental conditions, health, quality of housing and social infrastructure, an important strategic priority for the development of Krasnoyarsk agglomeration becomes a significant improvement of the quality of life.

To ensure the growth of the agglomeration's population by reducing the natural decline in population and migration flows, it is necessary to create the most comfortable conditions for life. This includes implementation of the following goals ${ }^{3}$ by 2020 :

1. To provide the population with affordable and qualitative housing by replacing the old housing and the construction of new housing in environmentally friendly areas, to achieve the level housing of 28 sq.m per capita.

2. To provide the access of the growing population to the social infrastructure, for which it is necessary to reconstruct and update healthcare institutions, to build diagnostic and rehabilitation centres, 68 schools and 96 kindergartens.

3. To create a variety of opportunities for rest and recreation of the population of the agglomeration, for which to open 12 museum-type organizations, cultural and leisure institutions, children's art schools, 97 libraries and 12 parks.

4. To create conditions for involvement of the population into mass and professional sports, for which to open 58 swimming pools, 120 sports halls, the centre of martial arts and a number of facilities for high performance sports.

5. To reduce the level of pollutant emissions into the atmosphere by $10 \%$ compared to 2007 , to encourage the use of modern industrial technologies to reduce emissions.

6. To increase the use of environmentally friendly private and commercial vehicles (electrified or using environmentally friendly fuel).
7. To ensure that public transport complies with the Euro-4 standard.

8. To reduce the time of interaction with the environment by using ground public transport (to minimize the waiting time for public transport, to introduce the stop-on-demand system to reduce heat loss).

9. To develop the telecommunications infrastructure to the level that ensures the opportunity to enjoy a wide range of services without leaving home, to compensate for severe climatic conditions.

10. To ensure the personal and property security of citizens by reducing crime. To make Krasnoyarsk one of the safest cities in Russia.

11. To ensure the safety of cultural and historical heritage of Krasnoyarsk and the region as a whole, namely, museum exhibits, library collections and architectural monuments.

\section{Infrastructure}

For the implementation of the above indicated economic objectives by 2020 , the following tasks in the field of infrastructure should be fulfilled:

1. To introduce at least 1,412 MVA of switching capacity to meet the growing electric power demands of the economy, which will be 85 HFC per year.

2. To construct an additional 1,200 $\mathrm{km}$ of roads to reduce the load of the road network, increase its capacity and ensure the smooth movement of people and goods in the agglomeration.

3. To ensure the accessibility of the Krasnoyarsk agglomeration from any major city in Russia and abroad.

4. To establish an international air hub on the basis of Emelyanovo airport for the implementation of the transit potential of Krasnoyarsk and increasing the attractiveness the Krasnoyarsk agglomeration for business and recreational tourism. 
5. To increase the transport connectivity of municipalities of the agglomeration, as well as transport accessibility of the agglomeration's heart by constructing new railways.

6. To build more than 880 thousand sq.m of high-quality warehouse spaces to meet the growing demand for commercial and industrial warehouses.

7. To meet business demand for quality office spaces through the construction of not less than 450 thousand sq.m of office spaces.

8. To create a scientific and innovation zone including scientific and educational institutions and infrastructure for the development of business in which the conditions for training personnel according to the needs of the economy will be created, as well as conditions for the development of small innovation business and commercialization of research developments.

9. To create a capacity for processing and recycling of $100 \%$ of solid waste generated in the agglomeration.

\section{Demography and migration policy}

To meet the demand of the growing economy for personnel it is necessary to ensure the migration inflow in the amount of 404 thousand people. Achieving this goal involves a number of tasks:

1. To increase the birth rate to the level of 16 children per 10 women.

2. To increase the number of births of three or more children in families up to $15 \%$ by government support and enhancement of the prestige of socially successful and large families.

3. To increase the average life expectancy to 75 years.

4. To initiate a range of measures to attract migrants to the agglomeration:

to create an attractive image of Krasnoyarsk as the best city for life and work; on a regular basis to carry out an information campaign through the media, the Russian embassy in the target countries, the Internet;

direct involvement of the target groups of migrants in the places where they live.

5. To initiate a complex of measures on the retention of migrants in the agglomeration:

to create in the agglomeration a highly segmented housing market meeting any demands

to stop the brain drain due to the support of most talented young specialists

to contribute to the settlement of the university graduates in the agglomeration, for this purpose to help in the beginning of the career, search and acquisition of housing, getting of a legal status (if necessary)

6. To minimize the bureaucratic barriers connected with registration and paperwork for arriving migrants.

7. To create a system of information and social adaptation for arriving migrants.

8. To provide affordable housing for migrants by allowing them to rent public housing, or acquire housing on favourable terms.

9. To ensure that migrants have access to various educational services, including the Russian language courses for people arriving from former Soviet republics and far abroad.

10. To ensure equal access for migrants to the social infrastructure of the agglomeration.

11. To give an opportunity to the migrants belonging to another culture or religion to hold meetings with the representatives of their culture and practice their religion. To do this, it is necessary to build cultural centres and religious sites.

12. To form a tolerant attitude among the native population towards migrants from other countries.

13. To adjust the activities of the authorities in terms of the migration policy to the interests of the migrant groups. 
14. To ensure that all changes in the field of the migration policy with the necessary legal framework at all territorial levels (as far as possible within the framework of federal legislation, the impact on which is extremely limited).

\section{Specialization of municipalities included into the Krasnoyarsk agglomeration}

Promising specializations of the municipalities included in the Krasnoyarsk agglomeration had been determined taking into account the development of various industries on their territory, the importance of preservation and renewal of traditional forms of management, strengthening and optimization of inter-municipal relations in the implementation of large projects in the social sector and infrastructure. At the same time one of the strategy objectives is the relative alignment of the development level in different municipalities.

\section{Krasnoyarsk}

The most promising economic sectors for the development of Krasnoyarsk are mechanical engineering, construction, commercial services, finances, tourism, research and education, and the social sphere. In addition, some industries (metallurgy, timber and chemical industries) are currently implementing major innovation projects.

\section{Divnogorsk}

Future prospects for the development of the city economy is seen in the development of tourism and mechanical engineering (production of power, electronic and optical equipment).

\section{Sosnovoborsk}

Among the most promising economic sectors for the development of Sosnovoborsk are metallurgy, timber industry, mechanical engineering and chemical industry. The development of the city will entail the development of the infrastructure (roads, electricity, water, etc.), as well as social development.

The convenient location of the city, ready industrial infrastructure, allocation of land plots for housing construction, favourable ecological conditions make Sosnovoborsk a ready platform for the transfer of some economic and social functions of the agglomeration centre, Krasnoyarsk. Moreover, Sosnovoborsk can perform some of the functions for the neighbouring municipalities (Zheleznogorsk and Berezovsky District).

\section{Emelyanovsky District}

The following industries are promising for the development in Emelyanovsky District: timber processing industry, mechanical engineering, construction, transport, trade, tourism and agriculture.

\section{Berezivsky District}

Future prospects for the development of the district economy is seen in increasing the production of innovative industrial products. Particular attention should be paid to construction materials, as well as the creation of large transport and logistics centres.

\section{Mansky district}

The most promising sectors for the development in the Mansky District are tourism, agriculture, food industry, timber industry and mining of raw materials for production of construction materials.

\section{Sukhobuzimsky Distrtict}

The most promising for the development are the following sectors: mining, metallurgy, timber industry, intensive agriculture and tourism.

\section{Key projects}

The list of investment projects is formed taking into account the main strategic goals of the Krasnoyarsk agglomeration until 2020. The major priority investment projects are aimed primarily at improving the quality of life of the 
agglomeration population; transformation of significantly different territories of municipalities into a single interrelated territorial system united not only by transport availability, but also aligned indicators of living standards; turning the agglomeration into the most attractive region of Siberia for life and work in order to not only keep the emerging outflow of population, but also to attract to the agglomeration high-quality human capital from other Russian regions and countries of the world.

In the economic sphere the priority initiatives and projects should be focused primarily on the growth of the innovation component; the increase of the level of the economy diversification; the use of the opportunities offered in connection with the growth of relatively close regions of Asia. Key initiatives in this area should be mainly focused on the work with potential investors, creation of a favourable business climate. The priority projects should include the creation of the Siberian Engineering Centre, the Global Sourcing Centre, Siberian Business School, the Centre of Technology Transfer and Scientific and Innovation Zone, technical innovation centers and technology parks.

To solve the problems arising due to severe climate, it is necessary to develop an infrastructure capable to compensate harsh temperature conditions for the residents. Promising projects in this area include, for example, the construction of all-weather (including underground), social and transport infrastructure to minimize the population's contact with the environment. For the purpose of changing the unfavourable ecological conditions it is necessary to carry out the work in terms of removal of the most hazardous industries from residential areas, the organization of the construction of new residential areas away from hazardous industrial facilities, encouraging enterprises to adopt advanced production technologies and treatment systems, reducing harmful emissions in the environment to the minimum level.

A separate list of projects and activities should be aimed at solving the problem of the territorial remoteness of the Krasnoyarsk agglomeration from major markets and business centres of the Russian Federation. Such projects, first of all, may include efforts to develop transport accessibility and connectivity of the agglomeration with the largest cities of Russia and the world, such as the development of general aviation, attracting low budget airlines, construction of high-speed railways.

The poorly developed network of cultural, educational and social institutions, as well as objects of energy, transport and industrial infrastructure also requires the implementation of infrastructure projects such as the construction of logistics and office complexes, housing construction, development of a network of electric power facilities, setting new educational, medical, sports, cultural and other institutions to work.

The government considers the following projects to be the most priority ones in terms of the economic and social effect:

1. Organization on the territory of the Krasnoyarsk agglomeration of scientific and innovation area, the Siberian Engineering Centre, the Global Sourcing Centre and the Centre of Technology Transfer to ensure transfer of industrial companies to a new technological level, which, in turn, will increase the competitiveness of the agglomeration economy and lead to an increase in the population's welfare and quality of life. Thus, the central component in the development of innovation-oriented industries in addition to the science and innovation centre will be the Siberian Engineering Centre, which will bring together the largest mechanical engineering with the aim of providing various engineering services, including design, feasibility studies, purchase of equipment, project management in construction, installation 
and commissioning, personnel training and organization of financing to industrial enterprises of the region and Russia as a whole. Establishment of the Engineering Centre will integrate not only Russian but also foreign suppliers of modern technologies, equipment and systems, will boost the efficiency of industries and sectors, from engineering and energy to agriculture, but mainly will contribute to the growth and modernization of industry in the agglomeration;

2. The construction of socially important facilities, aimed at creating a comfortable living environment and the improvement of living standards, among which: swimming pools, hospitals, kindergartens, schools, student dormitories, museums, cultural and leisure institutions, parks and gyms;

3. Increase of the housing stock of the Krasnoyarsk Agglomeration from 23.3 to 42 million sq.m. The project will increase the supply of the agglomeration's population with housing up to 28 square meters per 1 resident by 2020 ;

4. The construction of all-season (with artificial climate) social infrastructure, which allows to compensate unfavorable climatic conditions to the population;

5. Attraction oflow-costairlines and general aviation to the territory of the agglomeration, as well as construction of a high-speed railway between Novosibirsk and Krasnoyarsk, which will compensate for the problem of the territorial remoteness of the agglomeration and increase the mobility of people, goods and business;

6. Creation of conditions for the development of small business: providing easy purchase of manufacturing and office spaces equipped with all necessary utilities; simplification of procedures for registration and liquidation of business; organization of more effective interaction of entrepreneurs with the authorities and inspection bodies; ensuring the transparency of the business environment in the territory of the agglomeration and the provision of the necessary benefits. It is also planned to establish a centre of support to small business, which will represent the interests of entrepreneurs, organize effective interaction of entrepreneurship and large business, fulfill coordination and mediation functions in promotion of business products;

7. Development projects of road and transport infrastructure of the Krasnoyarsk agglomeration: $1,200 \mathrm{~km}$ of new roads; the construction of a bypass road "deep bypass" for better communication of scientific and innovation area to Emelyanovo airport and the centre of Krasnoyarsk; completion of construction of the underground;

8. Projects of energy infrastructure development of the Krasnoyarsk agglomeration: commissioning of 11 new transformer substations needed to eliminate power shortage in electricity transmission and enable the establishment of new industrial enterprises;

9. The construction of the Business Centre. The project will result in construction of more than 0.5 million sq.m of high-quality office spaces necessary to attract representatives of major global and domestic business to the Krasnoyarsk agglomeration and contributing to the development of small business.

10. Support for tourism at the territory of the Krasnoyarsk agglomeration. Among the key projects is the construction of hotels and country recreation houses, two ski resorts and amusement parks: water park, scientific and entertainment centre.

\section{Plan of implementation and main activities}

The implementation of the development strategy of the Krasnoyarsk agglomeration should be carried out in three stages:

1) Preparation;

2) Creating a basis for growth, restructuring and increase of efficiency; 
3) Active growth and expansion (Fig. 7).

The preparatory phase of activities will be primarily focused on overcoming consequences of the global financial crisis and other negative external factors, as well as creating the necessary conditions for the development of the agglomeration in compliance with the selected direction. The second stage will include activities related to the implementation of key projects and initiatives. The activities at the phase of active growth and expansion will be mainly maintenance of effective development of the agglomeration in accordance with the selected direction.

\section{Expected results from the implementation of the strategy}

\section{Economy}

Results of implementation of the priority strategicalternativedevelopmentoftheKrasnoyarsk agglomeration "Centre for Entrepreneurship and Innovations" should be changes in the structure of the economy; in the indicators reflecting the quality of life and degree of development of the basic infrastructure. In particular, the successful implementation of the strategy will increase the diversification of the economy and make it more balanced. It will increase the role of high-tech industries and innovation sectors resulting in growing competitiveness of the agglomeration's economy and make it less dependent on the situation at the world market.

The overall result characterizing the successful implementation of the strategic alternative, "Centre for Entrepreneurship and Innovations", will be the growth of the population's wealth.

In the service sectors the research and education centre designated as the kernel of this

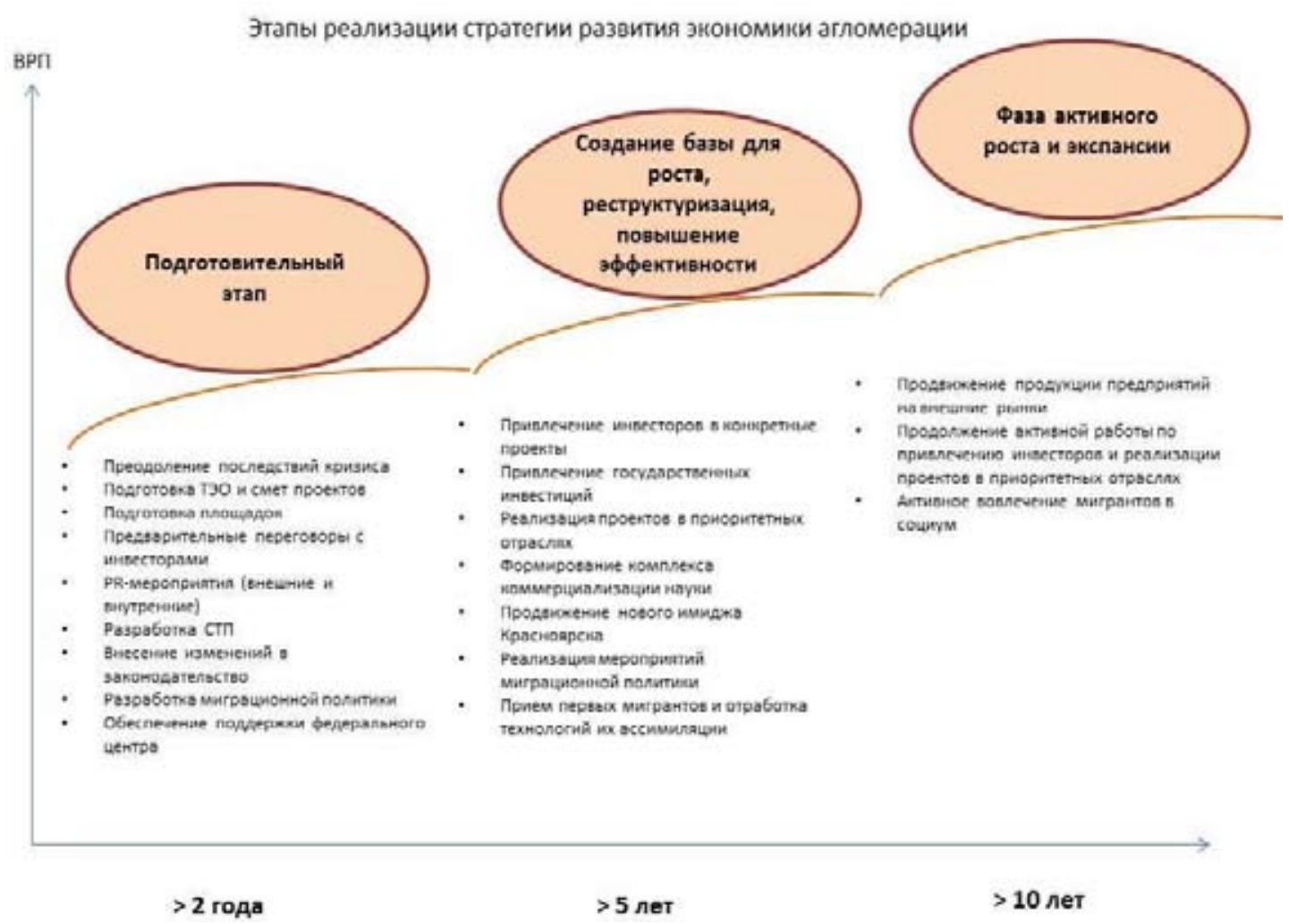

Fig. 7. Stages of implementation of the Krasnoyarsk agglomeration development strategy 


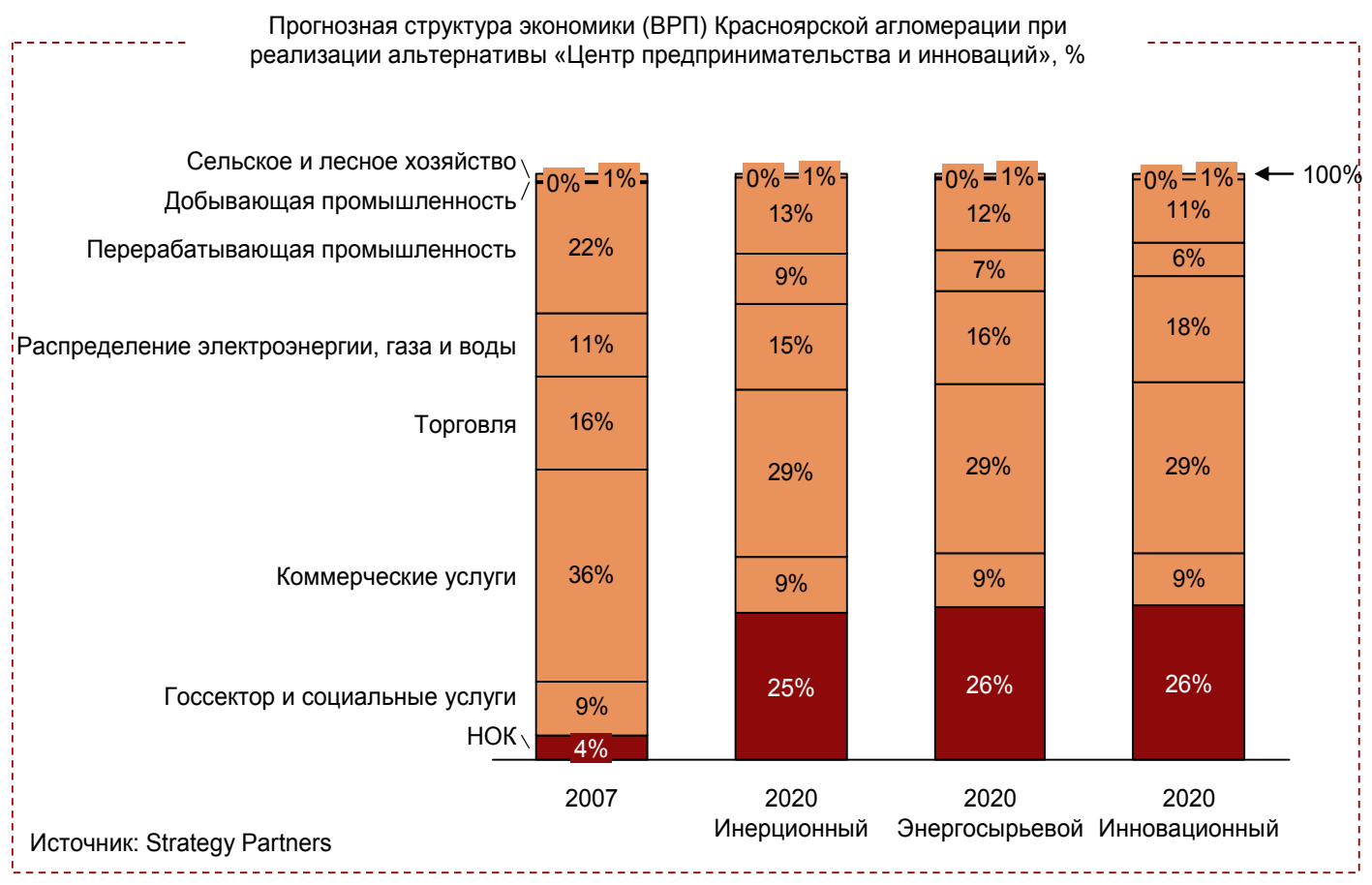

Fig. 8. Prospective changes in the structure of the Krasnoyarsk agglomeration economy

strategic alternative will take the leading position (Fig. 8). The role of tourism will increase. The service sector, as well as production and processing ones, will become more diversified and will be no longer determined by the general level of development of the territory's economy, which will reduce the structural risks of the economy of the Krasnoyarsk agglomeration.

In addition to structural changes in the economy, the implementation of the priority strategic alternative will create the necessary conditions for attraction of small business to the territory of the agglomeration and development of business, the contribution of which to the economy of the agglomeration will reach $50 \%$ level. In particular, the efforts of the municipal administrations will be focused on ensuring that businesses will be able to easily purchase industrial and office spaces equipped with all necessary utilities; simplification of procedures for registration and liquidation of business; organization of more effective interaction of entrepreneurs with the authorities and inspection bodies; ensuring the transparency of the business environment in the territory of the agglomeration and the provision of the necessary benefits.

As a result of the changes, the economy of the Krasnoyarsk agglomeration will become more competitive in terms of innovations and human capital. The knowledge-intensive and innovative sectors will be the engines of the entire economy making the Krasnoyarsk agglomeration the centre of effective interaction between science, education and business, a backbone region for the process of revival of Siberia and the Far East.

In terms of living conditions, the changes in the economy will lead to significant consequences such as the growth of employment and increase of the average monthly wage.

\section{Infrastructure}

Taken together, all the initiatives to develop the infrastructure in the Krasnoyarsk agglomeration implemented within the 
framework of the strategic alternative, "Centre for Entrepreneurship and Innovations", will allow the agglomeration to create the necessary basic conditions for economic development and growth of business activity, as well as create favourable conditions for life, work and recreation.

Significant improvements, in particular, will affect the energy infrastructure: twelve new transformer substations will be commissioned with total distribution capacity of 1,412 MVA, which will increase the capacity of the distribution networks of the agglomeration and meet the growing needs of industry, community facilities and population in electric power at the level of 80 thousand HFC per year. (Fig. 9).

In the transport infrastructure, significant positive changes will affect roads and railways, air hub and logistics spaces. The construction of 1.2 thousand $\mathrm{km}$ of roadway will increase the capacity of roads in the agglomeration and will improve the connectivity of the heart of the agglomeration with surrounding territories of semi-periphery and periphery (Fig. 10). Designing streets on the lattice principle, construction of the road section "deep bypass" and organization of parking areas, including underground ones, will help to reduce the load on the main roads of the agglomeration's kernel and provide more efficient movement of vehicles even in case of a growing number of cars.

In the field of the railway infrastructure it is expected to introduce additional routes between the municipalities, the members of the Krasnoyarsk agglomeration; construction of a high-speed railway connecting the airport, science and innovation area and the railway station of Krasnoyarsk; construction of the underground; as well as construction of a high-speed railway between Krasnoyarsk and Novosibirsk in the future. Implementation of these projects will greatly decrease the burden on the existing traffic arteries. To the greatest extent this will affect roads and intersections located in the centre of Krasnoyarsk, where the expansion of the roadway is not possible due to the high density of buildings, and the load on which can be reduced through the construction of the underground. An additional advantage of the underground construction will

Передача (потребление) электроэнергии в Красноярской агломерации, тыс. ТВчас.

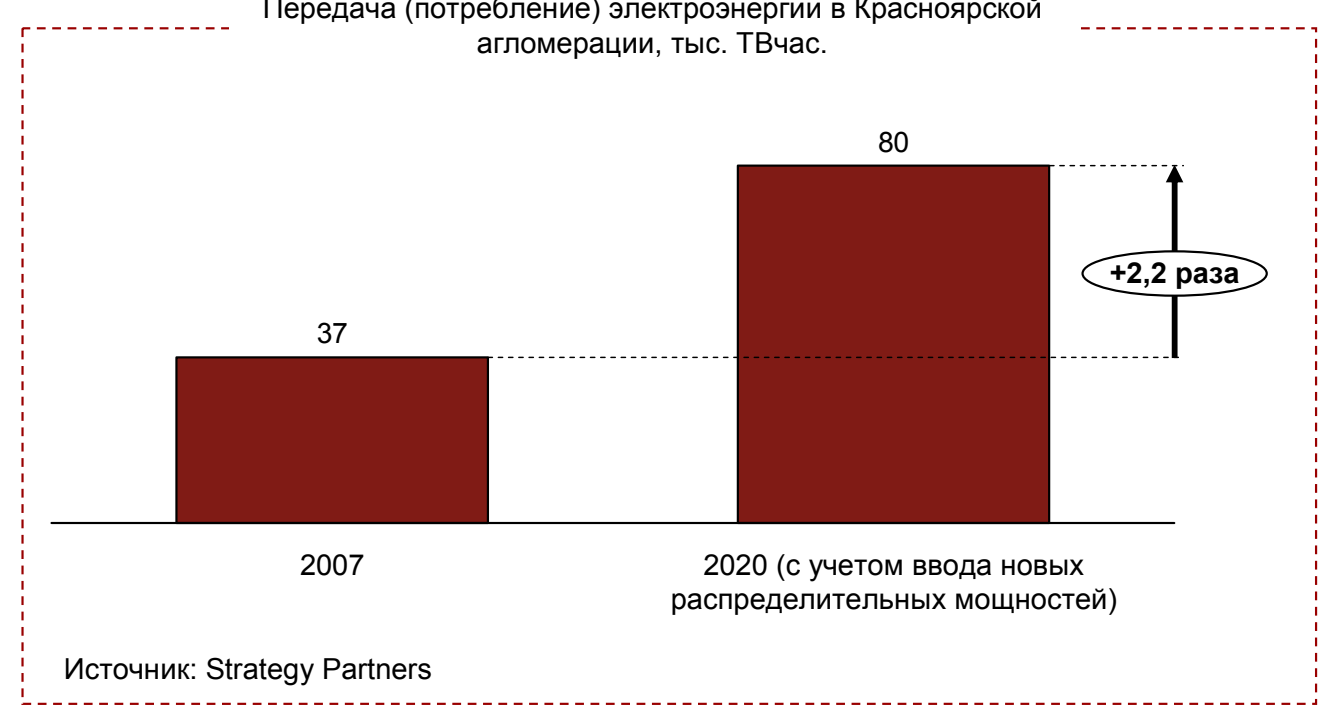

Fig. 9. Current and prospective transfer of the electric power in the Krasnoyarsk agglomeration in case of implementation of the strategic alternative, "Centre for Entrepreneurship and Innovations" 


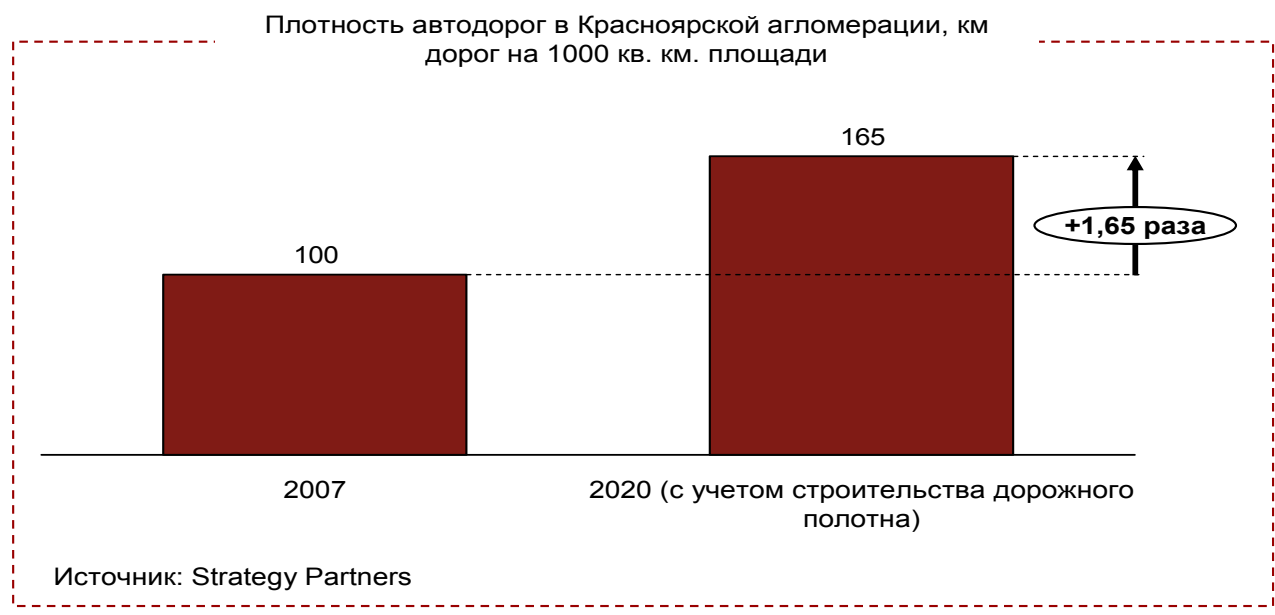

Fig. 10. Current and prospective density of road traffic in the Krasnoyarsk agglomeration in case of implementation of the strategic alternative, "Centre for Entrepreneurship and Innovations"

provide the population with the opportunity to move around the city in a transport system closed from the external environment, where comfortable temperature conditions are created.

Major infrastructure changes for air transport will affect the expansion and modernization of Emelyanovo airport, which will become a major international hub with the development of the logistics capabilities.

In addition to the above changes directly related to the transport infrastructure, the implementation of the strategic alternative provides for the construction of additional 882 thousand sq.m of high-quality warehouse spaces, primarily in the areas reserved for placing the international hub and special economic zone.

All these changes in the field of the transport infrastructure and logistics will help to effectively manage the increasing freight and passenger traffic in the Krasnoyarsk agglomeration (Fig. 11).

The business infrastructure will also be expanded by introducing additional 625 thousand sq.m of high-quality office spaces. Providing free access to the office spaces will be one of the factors increasing the attractiveness of the agglomeration for business including small business (Fig. 12).
The social infrastructure will be developed in the framework of the strategic alternative, "Centre for Entrepreneurship and Innovations" mainly to ensure the living conditions necessary to attract quality human capital to the agglomeration.

In particular, the amount of educational institutions, health facilities, sports and cultural institutions in the agglomeration will increase to the level that meets the requirements of the Russian legislation.

Due to construction of new housing and replacement of shabby housing in total exceeding 18 million sq.m, the provision of housing for the population of the agglomeration will increase from 20.2 to 28 square meters per person. Meanwhile, construction of residential buildings will be carried out taking into account all environmental requirements - far from the hazardous plants, in areas with significant number of green spaces (Fig. 13).

The communication infrastructure will be developed by providing $100 \%$ of the population access to broadband Internet versus $25 \%$ today. This will allow the population and business have an easy access to information, will provide an opportunity to order products 
Грузопоток в Красноярской агломерации, включая транзитный, млн. тонн

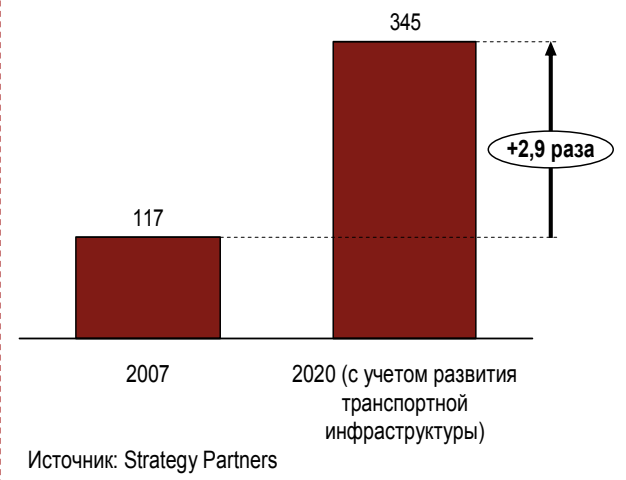

Пассажиропоток в Красноярской агломерации, включая транзитный, млн. чел.

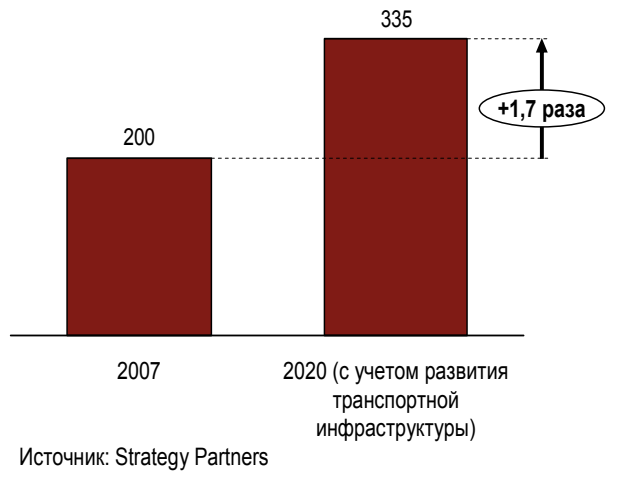

Fig. 11. Current and prospective freight and passenger traffic of the Krasnoyarsk agglomeration in case of implementation of the strategic alternative, "Centre for Entrepreneurship and Innovations"

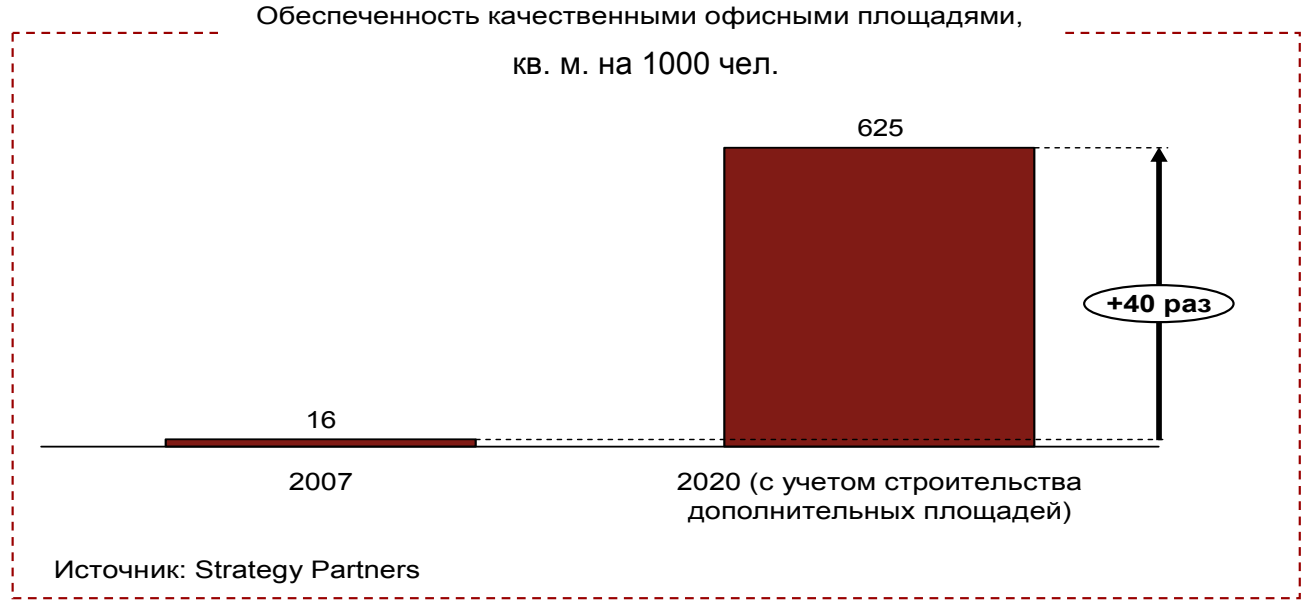

Fig. 12. Current and prospective situation with availability of high-quality office spaces in the Krasnoyarsk agglomeration in case of implementation of the strategic alternative, "Centre for Entrepreneurship and Innovations"

and services and share documents without leaving the room (Fig. 14).

In the utilities infrastructure about $1,056.3 \mathrm{~km}$ (in a single extent) of water pipes, about $591 \mathrm{~km}$ of sewage networks, about $227.5 \mathrm{~km}$ of heating networks, processing facilities for solid waste with total capacity of $1.1 \mathrm{mln}$ tons per year will be introduced into use. These projects will allow the residents of the agglomeration to obtain all the necessary utilities smoothly and in the necessary scope.

In the field of the recreation infrastructure in order to increase the attractiveness of the agglomeration for living and recreation it is planned to construct several year-round tourist and recreational facilities designed for 2.7 million visits per year; a year-round water park and a scientific amusement park "Museum of the Future" designed for 1.5 million visits per 


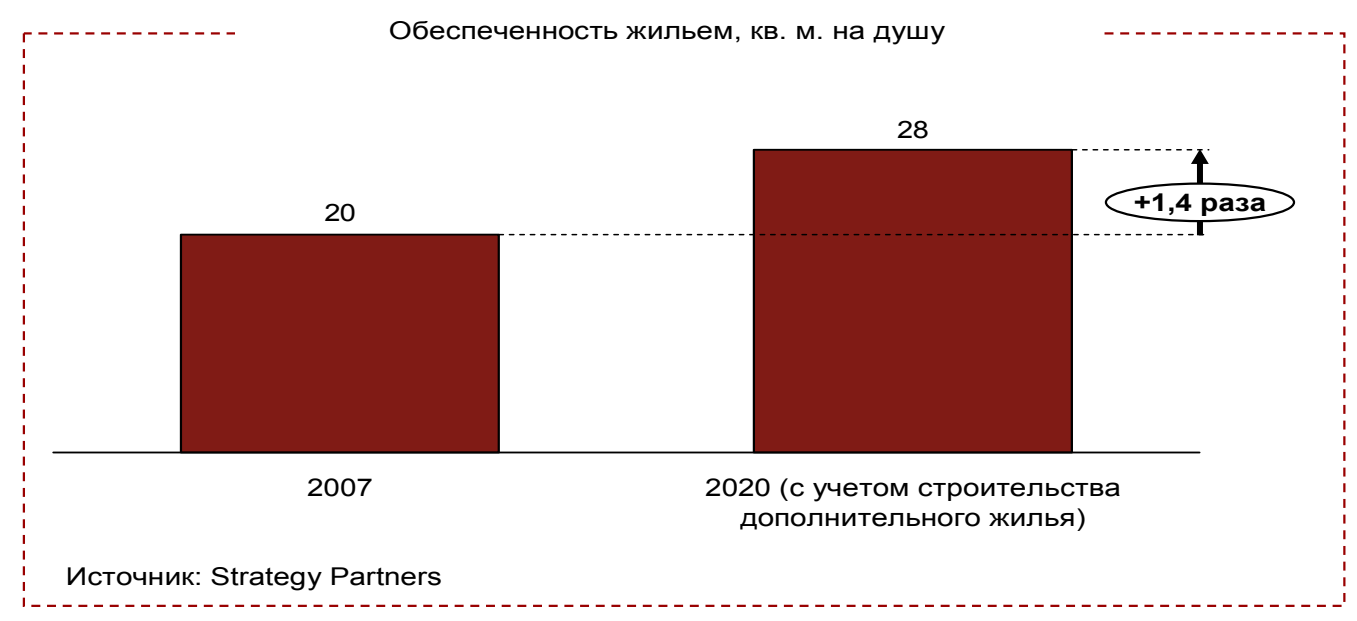

Fig. 13. Current and prospective situation with availability of housing in the Krasnoyarsk agglomeration in case of implementation of the strategic alternative, "Centre for Entrepreneurship and Innovations"

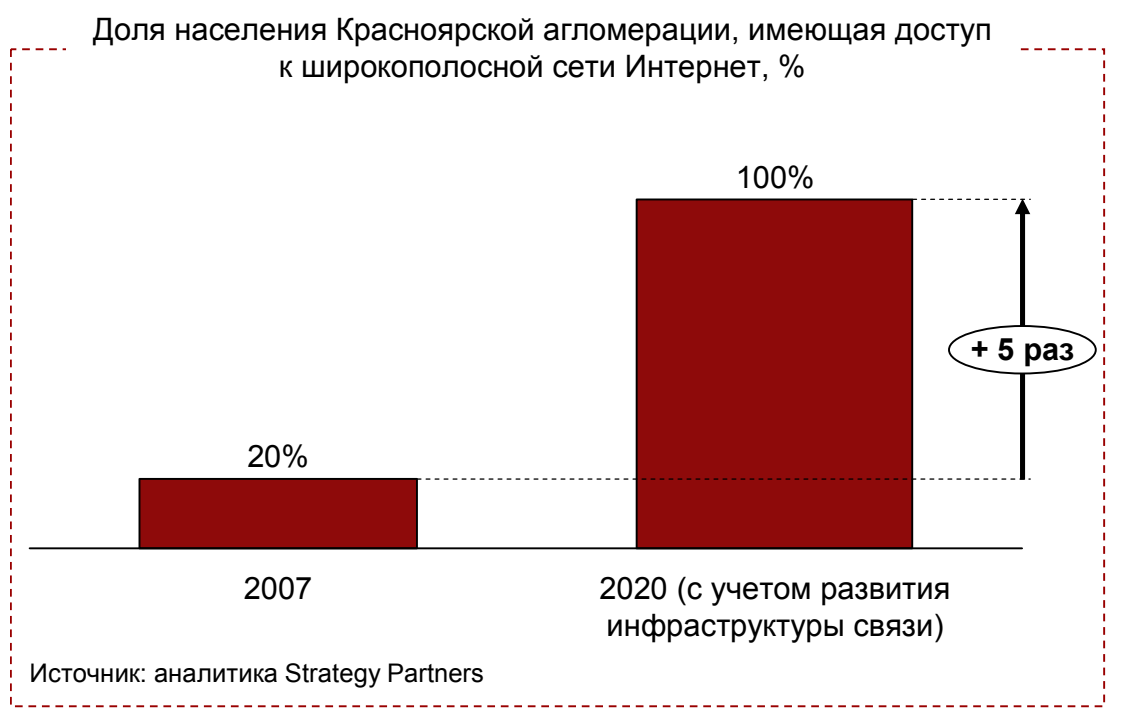

Fig. 14. Current and prospective amount of population in the Krasnoyarsk agglomeration with the access to broadband Internet in case of implementation of the strategic alternative, "Centre for Entrepreneurship and Innovations"

year. Also it is planned to commission 15 holiday vacation centres for 129 thousand visits per year, which together with the above mentioned facilities will enhance the ability of residents and guests of the agglomeration for amusement. The construction of hotel complexes for 6.8 thousand places in turn will create more comfortable living conditions, both for tourists and for people engaged in business travel to the Krasnoyarsk agglomeration.

\section{Quality of life}

As a result of the implementation of projects and initiatives proposed in the framework of the strategic alternative, "Centre for Entrepreneurship and Innovations", the 


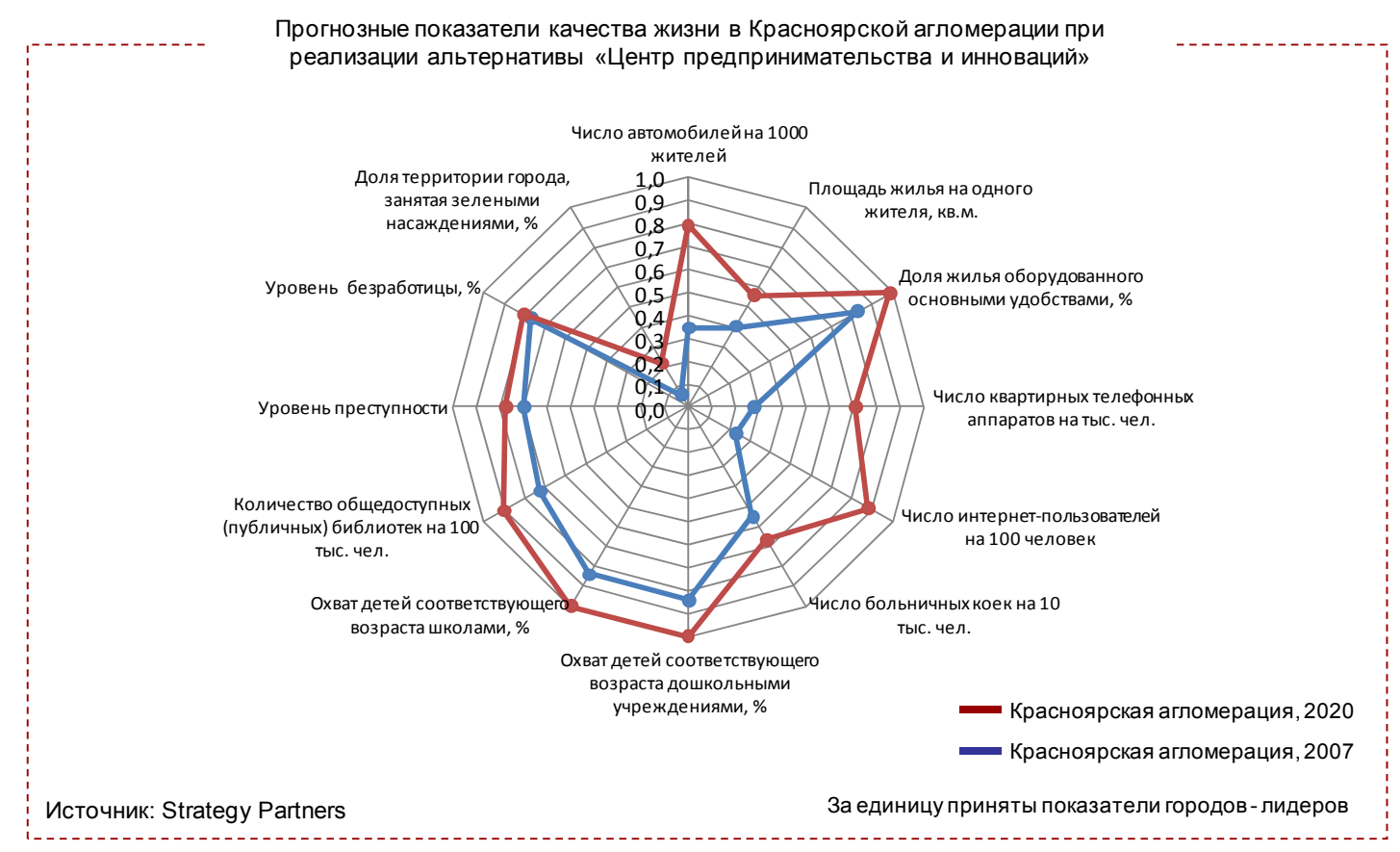

Fig. 15. Current and prospective indicators of the quality of life in the Krasnoyarsk agglomeration in case of implementation of the strategic alternative, "Centre for Entrepreneurship and Innovations"

Krasnoyarsk agglomeration can significantly improve the quality of life.

In particular, availability of housing and social infrastructure facilities will increase; the proportion of the population with access to broadband Internet will increase. The growing levels of income will allow the population to buy their own cars. The infrastructure development will create conditions for entertainment and recreation; and activities for the support of small business and economic diversification will open opportunities for self-realization.

Development of the transport infrastructure in conjunction with involvement in the agglomeration of low-cost airlines and the resumption of general aviation will reduce the negative effect of the territorial remoteness of the agglomeration and allow the people to move freely between the agglomeration and the largest cities of Russia and the world. Construction of the underground and its social infrastructure will compensate for severe climate by providing public access to the modern transport infrastructure in comfortable temperature conditions. Construction of new residential areas away from hazardous industrial facilities, as well as removal of the most hazardous enterprises from the proximity to residential areas and transition to modern technologies of production and emission treatment systems will reduce the harmful effects of environmental problems on human life and health. Activities in the area of crime reduction will make the city a safer place to live.

According to forecasts by the selective list of the quality of life indicators in case of the successful implementation of the strategic alternative, "Centre for Entrepreneurship and Innovations" in the Krasnoyarsk agglomeration by 2020 will be able to become close to the world leading cities in terms of quality of life (Fig. 15).

The overall growth of the economy and welfare, the development of basic infrastructure, compensation of severe climatic and environmental conditions, as well as the territorial remoteness of the region, 
economic diversification and creation of conditions for the development of the business environment will help to create the image of the Krasnoyarsk agglomeration, as the most attractive region for living, working, recreation and personal fulfillment. The overall results of the implementation of the strategic alternative, "Centre for Entrepreneurship and Innovations", will be the population growth in the agglomeration up to $1.5-1.6 \mathrm{mln}$ people.

\section{Organizational and legal model of the agglomeration}

Experience shows that the development of agglomerations is most effective when there are management models that provide sufficient flexibility in decision-making, taking into account the interests of different territorial communities, the rights of territorial units (including (in the federal state) the specific rights of the subjects of the Federation). On the contrary, rigid and centralized management is not always justified, as it bears the risk of underestimating the possibilities of development of different territorial entities, rapid bureaucratization of the agglomeration management system. On the other hand, excessive fragmentation of the management system carries the risk of losing control over the development of the agglomeration and loss of its subjectivity, which may lead to desynchronization of the processes in the agglomeration and loss of its development rates.

The management models of urban agglomerations can be quite efficient, when there is a single institutional decision-making mechanism with jurisdiction over the whole territory of the agglomeration, but a high degree of autonomy of internal territorial entities and communities is permitted that may be achieved by:

- Predomination of collegial authorities elected by indirect voting in municipalities - the agglomeration "subjects";

- registration of a significant part of the decisions in the form of public agreements and contracts between the "subjects" of the agglomeration; in general, the development of contractual forms of the agglomeration governance while maintaining a unified system of administrative decision-making;

- transfer of corresponding functions of management and development of interterritorial (intermunicipal, interregional or other) enterprises, corporations, agencies, etc.; development of the interterritorial system of public property management;

- development of collegial and contractual forms of budget process management on the territory of the agglomeration.

In the current legal conditions the choice of the management system for the Krasnoyarsk agglomeration is limited by $\mathbf{2}$ models known in the international practice:

Two-level management model;

Contractual management model.

Signing of the Agreement on the organization and implementation of the inter-municipal investment project "Integrated development of the Krasnoyarsk agglomeration for the period till 2020 " on April 17, 2008, between 3 urban districts and 4 municipal districts can be considered as the first step towards the establishment of contractual management mechanisms for the Krasnoyarsk agglomeration. It is advisable to continue to follow the path of expanding the cooperation, interaction, to develop and use specific forms of municipal cooperation. Later (in the case of adoption of an appropriate legislative framework at the federal level) it is possible to establish at the territory of the Krasnoyarsk agglomeration a "top" level municipality. Then it is the local government of the territorial level that would have the right to make decisions on general agglomeration issues.

International practice allows us to consider a two-level model of municipal agglomeration management as a sufficiently effective mechanism for dealing with common affairs, but its applicability in today's Russian conditions and, 
in particular, to the Krasnoyarsk agglomeration, has some serious limitations.

\section{Requirements to urban planning decisions}

The implementation of the development strategy for the Krasnoyarsk agglomeration should require appropriate planning decisions based on following principles: the plurality of development poles; taking into account of climatic features; landscaping, creation of green spaces, creation of sanitary zones, regional gaps.

In addition, spatial planning of the agglomeration must take account growing demand for housing, social and other infrastructure.

1 As of the period of development of the "Strategy of the socio-economic development of the Krasnoyarsk agglomeration until 2020"

2 Investments into the economy of the private sector, expenditures of the budgets of all levels for the development of the economy and social sphere including organizational arrangements

3 Objectives in the field of the social infrastructure are evaluated on the basis of the forecasts of the population growth and standards of well-being determined by the federal laws and regulations

\title{
Красноярская агломерация: идея и перспективы развития
}

\author{
В.И. Полищук \\ OAO «Корпоращия «Красноярск-2020» \\ Россия, 660075, Красноярск, Республики, 51
}

Статья подготовлена на основании материалов «Стратегии социиально-экономического развития Красноярской агломерачии до 2020 года», разработанных в 2008-2009 г2. ОАО «Корпорачия «Красноярск-2020» в соответствии с государственным контрактом № 6/2008-ГК от 28 июля 2008 года. В ходе выполненной работы по сочиально-экономическому анализу и планированию процессов ускоренного инновачионного комплексного развития семи муниципальных образований (Красноярской агломерации) с ядром агломерации - городом Красноярском был произведен многофакторный анализ текущего состояния и перспективных направлений социально-экономического развития «агломерированных» территорий. Были учтены факторы внутристрановой и международной экономико-политической конкуренции территорий, а также исторически сложившееся геоэкономическое положение Красноярской агломераиии, достигнутый к 2008 году промышленный, экономический, культурно-образовательный и социальный уровни развития и потенциал дальнейшего роста. В статье рассмотрен горизонт планирования до 2020 года.

Ключевые слова: региональное развитие, Красноярская агломераџия, стратегия сочиальноэкономического развития, инновационное развитие региона, модернизация экономики Красноярского края.

По материалам «Стратегии сочиально-экономического развития Красноярской агломерации до 2020 года», разработанной в соответствии с государственным контрактом № 6/2008-ГК от 28 июля 2008 года.

Научная специальность: 08.00.00 - экономические науки. 
